\title{
E-Commerce to Multinational Conglomerate: Journey of Alibaba Group - A Case Study
}

\author{
Yogish Pai U. ${ }^{1}$, \& K. G. Nandha Kumar ${ }^{2}$ \\ ${ }^{1}$ Research Scholar, College of Computer Science and Information Science, Srinivas \\ University, Mangalore, India \\ ORCID-ID: 0000-0002-4266-2809; Email: yogish77pai@gmail.com \\ ${ }^{2}$ Associate Professor, College of Engineering and Technology, Srinivas University, India \\ ORCID-ID: 0000-0002-5716-7122; Email: professorkgn@gmail.com
}

Area of the Paper: Information Technology.

Type of the Paper: Research Case Study.

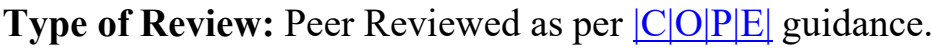

Indexed In: OpenAIRE.

DOI: http://doi.org/10.5281/zenodo.4544394

Google Scholar Citation: $\underline{\text { JCSBE}}$.

\section{How to Cite this Paper:}

Yogish Pai, U. \& Nandha Kumar, K. G., (2021). E-Commerce to Multinational Conglomerate: Journey of Alibaba Group - A Case Study. International Journal of Case Studies in Business, IT, and Education (IJCSBE), 5(1), 25-35. DOI: http://doi.org/10.5281/zenodo.4544394.

International Journal of Case Studies in Business, IT and Education (IJCSBE)

A Refereed International Journal of Srinivas University, India.

(C) With Authors.

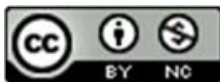

This work is licensed under a Creative Commons Attribution Non-Commercial 4.0 International License subject to proper citation to the publication source of the work.

Disclaimer: The scholarly papers as reviewed and published by the Srinivas Publications (S.P.), India are the views and opinions of their respective authors and are not the views or opinions of the S.P. The S.P. disclaims of any harm or loss caused due to the published content to any party. 


\title{
E-Commerce to Multinational Conglomerate: Journey of Alibaba Group - A Case Study
}

\author{
Yogish Pai U. ${ }^{1}$, \& K. G. Nandha Kumar ${ }^{2}$ \\ ${ }^{1}$ Research Scholar, College of Computer Science and Information Science, Srinivas \\ University, Mangalore, India \\ ORCID-ID: 0000-0002-4266-2809; Email: yogish77pai@gmail.com \\ ${ }^{2}$ Associate Professor, College of Engineering and Technology, Srinivas University, India \\ ORCID-ID: 0000-0002-5716-7122; Email: professorkgn@gmail.com
}

\begin{abstract}
The late 20th century witnessed a massive growth in the usage of Internet worldwide. Many eCommerce companies blossomed during this era. Realizing the need of having e-commerce business in China, Alibaba.com got established by former English teacher Ma Yun, popularly known as Jack Ma, along with 17 other partners. During the dot com bubble burst, many of the US based e-commerce companies' either had to shut down or went bankrupts except Chinese based Alibaba.com as Chinese market was immune to the recession. Clear vision and intelligent leadership quality of Jack Ma turned e-commerce Company into a largest online commerce company of China within a short span of time. Alibaba continued its journey of growth both organically and inorganically by acquiring other companies. Later in 2009 Alibaba group entered into cloud computing business, and started to develop artificial intelligence solutions to support its own platform and to solve complex real-world problems. Alibaba diversified its revenue sources by expanding business to different domains within two decades of its inception to reach US $\$ 72$ billion. Presently, the Alibaba group has pioneered in consulting, e-commerce, finance, technology, artificial intelligence and many more. The study in this paper describes how the Alibaba group continued its journey towards success along with business model, major businesses, financial status and corporate social responsibility. To understand the strengths, weaknesses, opportunities and challenges of the Alibaba group, a methodical SWOC analysis was conducted. Based on the SWOC analysis, some recommendations are also provided.
\end{abstract}

Keywords: e-commerce, Alibaba, Jack Ma, cloud computing, Artificial Intelligence.

\section{INTRODUCTION :}

When the opportunity for Chinese manufacturers to sell their products on internet was bare minimum, Jack Ma realized the need of having a common platform to bring both suppliers and buyers together to sell and buy the product via Internet. As a result, the inception of Alibaba.com, a business to business (B2B) trade platform was established on 28th of June 1999 in a small apartment of Chinese city named Hangzhou. There were around 17 more partners who joined with Jack Ma to support him with his novel idea. Year later Alibaba could raise \$25 million financing from Softbank and other investors. The political and economic transformation resulted to improved lifestyle for middle class customers and Internet access to majority of the population. This set a right platform for E-commerce business in China and within three years of establishment, Alibaba was able to record its profit in the year of 2002 [1]. Soon Alibaba group launched a consumer to consumer retail website known as Taobao.com. The introduction of Alipay, an online payment platform developed by Alibaba set a stage to conquer the Asian online marketplace. In 2007 Alibaba went public in Hong Kon and on its 10th anniversary; it launched its cloud computing platform, which turned out to be one of the four major key business units later. Core Commerce, Alibaba Digital Media and Entertainment, Innovation initiatives and others are rest of the three key business units. Alibaba operates several companies including acquired companies such as HiChina, Ele.me, Vendio, Lazada, Kaola, ChinaVision, Trendyol, YoukuTudou, Cainiao, etc [2]. So far, 32 acquisitions and 219 investments have been made by the Alibaba Group and recorded an overall revenue growth of $30 \%$ year-over-year as per the financial reports released on 30th September 2020 [3]. Initiatives taken by Alibaba group to reduce carbon emissions and electricity consumption 
were remarkable as they made use of renewable energy and environmentally friendly processes which set them to triumph. In the recent years Alibaba group is known as a largest spender in the field of research and development, which started focusing on artificial intelligence, Machine learning, Data mining etc. Alibaba has made lot inventions and one of them is ET-Brain which is a clever artificial intelligence platform to provide a resolution to complicated social and business-related problems. As of 2020, Alibaba turned out to be a sixth most valuable company globally with 757 million annual active customers.

\section{OBJECTIVES :}

This case study has been conducted to understand various factors that led Alibaba Group to be a successful Company in the last two decades. Primary objectives of the paper are listed below-

(1) To study the business model of Alibaba Group holding company.

(2) To explore the journey of Alibaba Group since last two decades.

(3) To understand the corporate social responsibility of the Alibaba Group.

(4) To recommend improvements in the current performance based on the result of SWOT Analysis.

\section{METHODOLOGY :}

Case study has been conducted by referring secondary data such as information published on Journals and Conference Proceedings, Company Websites, Internet Articles, Focus Group Discussions, Books and SWOC Analysis Framework, as per the company analysis procedure [4].

\section{OVERVIEW OF ALIBABA GROUP :}

\subsection{Business Model:}

Alibaba generates its revenue from its services through four key business units such as core commerce, cloud computing, digital media and entertainment and innovation initiatives and others [5]. It stands unique in the market because of its business model.

(1) Core Commerce: Even though it is an ecommerce company it brings both buyers and sellers on single platform but doesn't buy, store or sell anything by itself. The three key businesses of the unit are Alibaba, an e-commerce platform for business-to-business (B2B), Tmall a platform for business-toconsumer (B2C), Taobao; and a platform for consumer-to-consumer. Three large websites owned by respective key business namely alibaba.com, taobao.com, and tmall.com are on top ten lists in the ecommerce market [6].

(2) Cloud computing: Enterprise cloud products and services such as database, elastic computing, storage, security, big data analytics, machine learning (MI) and Internet of Things (IoT) platform are offered by Alibaba Cloud to its enterprise customers [7].

(3) Alibaba Digital Media and Entertainment Group use the business data of Alibaba to provide consumers with a robust digital media and entertainment platform to explore and consume content and communicate with each other. The unit generates revenue primarily from the services of customer management and membership fees.

(4) Innovation initiatives and others unit is established to meet the requirements of customers of Alibaba's by development and innovation of new services and products. Primary revenue generation is by charging service fees and selling in-house products to the large enterprise customer base.

Core commerce is the primary source of revenue for Alibaba followed by Cloud computing, Digital Media and Entertainment and finally innovation initiative group. In conquering the consumer market in the United States, Alibaba has had modest success so far. Alibaba Group neither holds inventory nor owns any warehouses instead has developed software products that makes it easier to exchange products and services. Although the revenue of Alibaba is lower than those of Amazon, it is one of the largest operating group with huge profit margin. Alibaba has also invested in several businesses such as Zulilly, SnapChat, and Lyft in the United States [8].

The inorganic growth of Alibaba began with the acquisition and adaptation of its competitors to the platform to fulfill the needs of customers and enhance service quality. In 2000, Alibaba introduced a gold supplier strategy to enable suppliers to purchase premium membership that would offer additional benefits such as seal of authenticity in the form of a Golden icon displayed on their website. This helped 
suppliers to rank at the top while searching for and helps to win customers' trust. Due to recession in the year, the global financial crisis prompted the Chinese government to release measures to improve the domestic market, which actually helped local players like Alibaba [9].

\subsection{Major businesses:}

Alibaba operates at a larger scale and is supported by several other companies for services associated with its digital economy. Significant companies in the digital economy of Alibaba include [7][10]:

4.2.1 Taobao Marketplace, established in 2003, brings retailers, buyers and opinion leaders to connect, discuss and understand the product on the same platform by allowing communication networks via their website. This reality gives consumers a customized shopping experience. The majority of the merchants in Taobao are primarily individuals and owners of small businesses.

4.2.2 Tmall, is renowned for its high-quality products and premium shopping experience. Chinese and foreign customers both use Tmall to purchase domestic and international branded goods. It was launched in 2008 and is considered to be the largest online and mobile Third Party site for brands and retailers.

4.2.3 Freshippo, a grocery retail chain launched in 2008, provides its customers the experience of both in-store and online shopping. Customers can pick items of their choice and the delivery system guarantees that products are shipped by 30 minutes to customers who live within 30 kilometers of store radius. A smartphone app helps users to review the details of each item and then place the order while shopping in the store.

4.2.4 Aliexpress, helps customers from all over the world to directly purchase goods from distributors and producers in China and other countries. Aliexpress is popular since its launch in 2010, in many nations like the United States of America, Brazil, Russia, France and Spain.

4.2.5 Lazada, that was established in 2012, is a pioneering and swiftly rising e-commerce marketplace for Small and medium enterprises, domestic and international brands and has left its footprint in six countries of Southeast Asia. Not only that, it offers customers access to a wide variety of products in the 12 months that ended in March 31, 2020, reaching over 70 million unique consumers.

4.2.6 Alibaba.Com, the very first company is now China's largest organized global online wholesale platform, connecting local and foreign suppliers to global customers and offering manufacturing, digital marketing, digital logistics and financial services.

4.2.7 1688.Com, a wholesale domestic marketplace that was launched in 1999 links producers and wholesalers to wholesale customers in China who usually trade in clothing, general merchandise, packaging materials, accessories, interior decoration, furnishing materials, etc.

4.2.8 Ele.Me, is the largest on-demand and regional service platform in China. It allows customers to use Ele.me, Koubei, Alipay, and Taobao phone apps to buy grocery items, food and beverage online.

4.2.9 Youku, is China's third biggest online video portal. It helps the visitors to search quickly and easily, watch also share premium quality videos on different devices.

4.2.10 Dingtalk, is an enterprise-level networking and collaboration technology that facilitates remote employees to connect with each other through text messages, voice messages, images, documents and mail. This tool also offers audio conferencing facilities for no more than 30 individuals and handles internal workflows such as employee vacation, travel requests and reimbursement.

4.2.11 Alimama, was launched in 2007 and is an advertisement tool that enables web publishers and marketers to transact online and advertising their inventories. 
4.2.12 Alibaba Cloud, that was founded in 2009, is known as the intelligent technology backbone of the Alibaba Group, that offers a wide range of cloud services such as storage, database, network virtualization, big data analytics, Internet of Things and machine learning. As a service provider in 2019, Alibaba cloud is considered to be Asia Pacific's largest infrastructure.

4.2.13 The Cainiao Network, founded in 2013 is exclusively set up to fulfill the logistics vision of the Alibaba Group to deliver goods within a day in China and within three days to any foreign venue. It addresses a variety of problems related to the logistics needs of sellers and buyers.

4.2.14 Ant Group, Wide spread online payment network- ALIPAY is part of Ant group, Ant Group is leading the development of open technology solutions for wide-ranging financial services.

\subsection{Journey toward success:}

A business to business (B2B) site established in the year of 1999 by Jack Ma and his 17 friends later emerged as an e-commerce giant competing with worlds topmost companies like Amazon and eBay. Alibaba has gone through several phases on the road toward being such a successful organization, an overview of the same can be seen below [11].

1999: Inception of the company by Jack Ma and other 17 partners in Hangzhou, China.

2000: The Company attracts $\$ 25$ million in financing from giant investing firms such as Fidelity Investments, Softbank and Goldman Sachs, etc.

2002: Alibaba recorded a maiden profit.

2003: Consumer centric e-commerce site, Taobao has been rolled out to facilitate its customers.

2004: Alibaba develops and introduces its own payment system, Alipay, which later became one of the largest payment systems in China.

2005: Yahoo handed over its Chinese operations to Alibaba.

2007: Alibaba.com went public in Hong Kong and was listed on the stock exchange.

2008: Online retail, business-to-consumer site Taobao Mall launched to enable merchants to sell their products directly to customers.

2009: Cloud computing platform was launched when Alibaba celebrated its 10th anniversary.

2010: Online stores were established by Gap and Ray-Ban at Taobao Mall, which formed a new benefit route for U.S. companies doing business in China.

2013: Jack Ma is standing aside as Alibaba's CEO. Jonathan $\mathrm{Lu}$, the hand-picked heir to Ma, replaces him.

2014: Alibaba is on the rise to become the leading online trading platform for small and medium-sized enterprises. The company went public on the New York Stock Exchange shall trade in the same year.

2015: The new CEO, Daniel Zhang, took over the charge on May 10.

2018: Ma revealed his intention to retire as CEO of the company within the next 12 months and to install CEO Zhang in his place.

2019: Signed an agreement to setup Electronic World Trade Platform Hub in Ethiopia.

2020: Jack Ma stands down as chairman of one of the largest Chinese industry giants.

\section{FINANACIAL :}

Being a holding company headquartered at Cayman Islands, Alibaba runs its e-commerce businesses through its subsidiaries and variable interest entities located in China. As per $30^{\text {th }}$ September 2020 financial reports Alibaba recorded an overall revenue growth of 30\% year-over-year. Due to the digital transformation across majority of the business sectors, demand for cloud solution increased and resulted in revenue growth of Cloud computing group by $60 \%$ year-over-year. Annual active customers in the Chinese retail market amounted to 757 million, a rise of 15 million over the 12-month period ended 30th June 2020 [12]. Core Commerce revenue was US\$19.3 billion, up 29 percent year-on-year, with extensive product supply and consumer experience driving market growth and higher buying behavior. As of 30 September 2020, approximately 60 per cent of the companies listed on the A-Share market are on the Alibaba Cloud User List and the average expenditure of those companies has increased by 45 per cent year-over-year. Youku, A video hosting service provider observed an increase of 45 per cent year over year in the average daily subscriber base [13]. 
International Journal of Case Studies in Business, IT, and Education (IJCSBE), ISSN: 2581-6942, Vol. 5, No. 1, February 2021

SRINIVAS

Alibaba Group Holding Limited Revenue Growth (in \%)

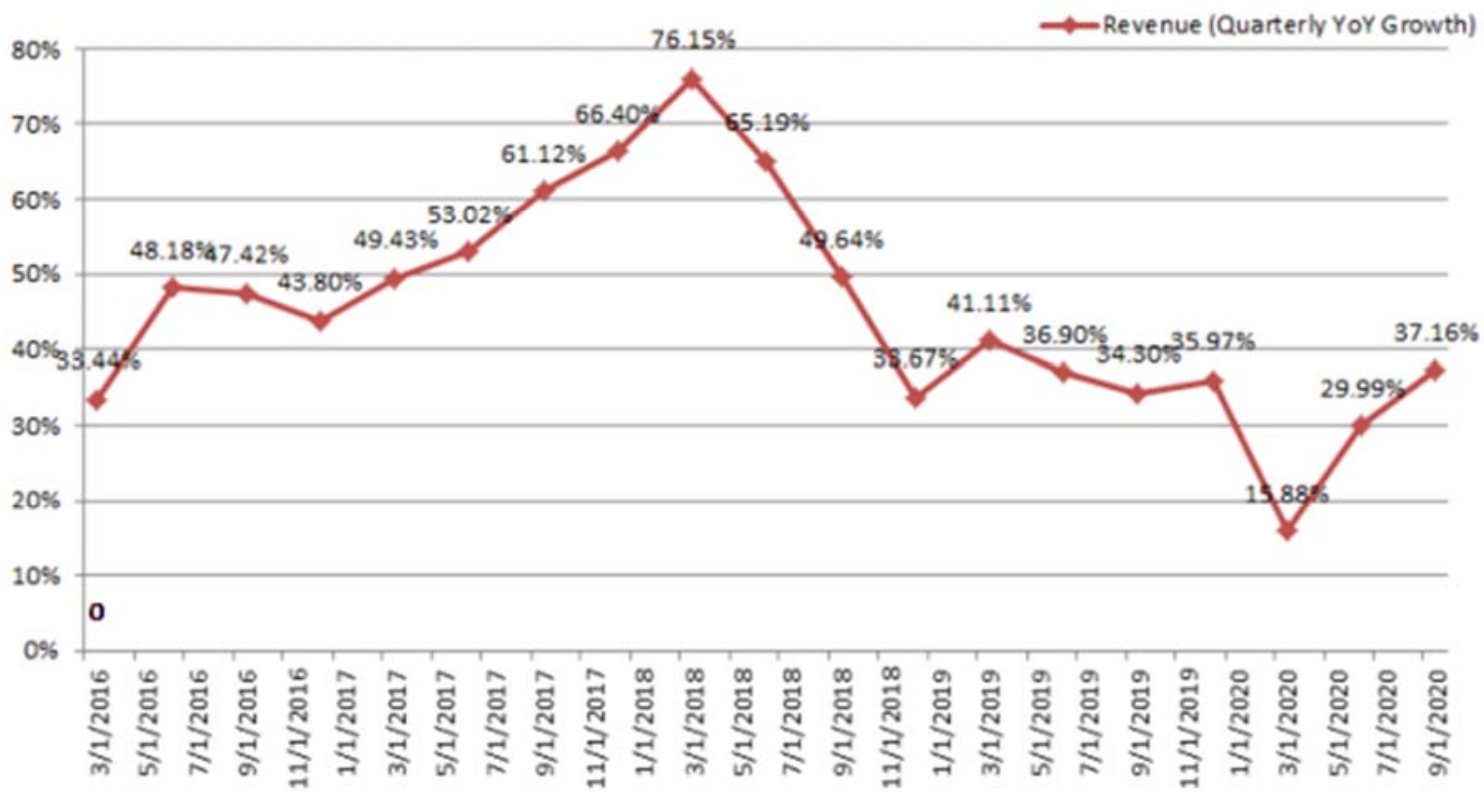

Fig. 1: Revenue Growth chart of Alibaba Group Holding Ltd [14].

Due to the improved domestic market sales that led to the global turnaround of Covid-19, benefited Alibaba, the gross domestic product grew 4.9 percent.

Table. 1: Alibaba Revenue (Quarterly YoY Growth) [14].

\begin{tabular}{|r|r|}
\hline \multicolumn{1}{|c|}{ Year } & $\begin{array}{l}\text { Revenue (Quarterly } \\
\text { YoY Growth) }\end{array}$ \\
\hline $3 / 31 / 2016$ & $33.44 \%$ \\
\hline $6 / 30 / 2016$ & $48.18 \%$ \\
\hline $9 / 30 / 2016$ & $47.42 \%$ \\
\hline $12 / 31 / 2016$ & $43.80 \%$ \\
\hline $3 / 31 / 2017$ & $49.43 \%$ \\
\hline $6 / 30 / 2017$ & $53.02 \%$ \\
\hline $9 / 30 / 2017$ & $61.12 \%$ \\
\hline $12 / 31 / 2017$ & $66.40 \%$ \\
\hline $3 / 31 / 2018$ & $76.15 \%$ \\
\hline $6 / 30 / 2018$ & $65.19 \%$ \\
\hline $9 / 30 / 2018$ & $49.64 \%$ \\
\hline $12 / 31 / 2018$ & $33.67 \%$ \\
\hline $3 / 31 / 2019$ & $41.11 \%$ \\
\hline $6 / 30 / 2019$ & $36.90 \%$ \\
\hline $9 / 30 / 2019$ & $34.30 \%$ \\
\hline $12 / 31 / 2019$ & $35.97 \%$ \\
\hline $3 / 31 / 2020$ & $15.88 \%$ \\
\hline $6 / 30 / 2020$ & $29.99 \%$ \\
\hline $9 / 30 / 2020$ & $37.16 \%$ \\
\hline & \\
\hline
\end{tabular}

Yogish Pai U, et al, (2021); www.srinivaspublication.com 


\section{Cache flow statement}

For the period ended $30^{\text {th }}$ September 2020, Alibaba's free cash flow was 15,376.00, a year-over-year rise [15].

\section{CORPORATE SOCIAL RESPONSIBILITY :}

Founded in 2014 by Jack Ma, Executive Chairman of the Alibaba Group, the Jack Ma Foundation aims to foster the development of people in harmony with society and the environment. Its operation is aimed at a planet of bluer sky, cleaner water, and healthy communities [16]. In September 2015, the Jack Ma Rural Teacher Initiative was introduced by the Jack Ma Foundation to provide essential aid for rural community education. By encouraging their efforts and giving them opportunities for career development, the initiative seeks to acknowledge the important role of rural teachers. Data centers consume a major portion of electricity to keep the devices functional and maintain them in a specific temperature by deploying temperate controlling system. This obviously becomes a cause for increased electricity usage and carbon emission. Alibaba group has taken a lot of initiatives to reduce carbon emission and electricity consumptions by making use of renewable energy and environmentally friendly processes. Implementation of deep-water cooling system in their data center saves $300,000000 \mathrm{kWh}$ of electricity and reduces carbon emission 300,000 tons annually [17]. The logistics wing of Alibaba was redesigned to use renewable energy vehicles and bio-degradable packaging materials, resulting in 3.62 million tons of reduced carbon emissions [18]. In 2017, the Alibaba Poverty Relief Program was launched with the goal of ending poverty and supporting families and communities suffering from poverty. Women empowerment, healthcare, education environmental sustainability etc. are some of the areas covered by this initiative. Mission Million Books, a program launched in 2016, obtains books by contributions and supplies them to Indian schools and colleges that are unprivileged and weak. The goal of the initiative is to provide under-privileged students with quality learning materials. Model Mom Entrepreneurship that supports mothers from struggling families to set up their own businesses, Reunion platform to trace lost children etc. are a number of other projects initiated by the Alibaba Group to benefit people in need.

\section{COMPETITORS :}

As the Alibaba group has diversified its business platform, competitors can be seen in different sectors of the Internet Business. The key competitors of Alibaba are Qurate Retail Group, Coupang, ASOS, JD.com, Walmart, Best Buy and Amazon. Table.2 below gives comparison details of both domestic and international competitors of Alibaba.

Table. 2: Competitors comparison [19].

\begin{tabular}{|l|l|l|l|l|l|l|l|}
\hline & $\begin{array}{l}\text { Qurate } \\
\text { Retail } \\
\text { Group }\end{array}$ & Coupang & ASOS & JD.com & Walmart & Best Buy & Amazon \\
\hline $\begin{array}{l}\text { Date of } \\
\text { Establishm } \\
\text { ent }\end{array}$ & 1991 & 2010 & 2000 & 1998 & 1962 & 1966 & 1994 \\
\hline Type & Public & Private & Public & Public & Public & Public & Public \\
\hline Description & $\begin{array}{l}\text { Engaged } \\
\text { into video } \\
\text { commerce, } \\
\text { mobile } \\
\text { commerce } \\
\text { and social } \\
\text { commerce. }\end{array}$ & $\begin{array}{l}\text { A } \\
\text { platform } \\
\text { for e- } \\
\text { commerc } \\
\text { e serving } \\
\text { members } \\
\text { in general } \\
\text { mass } \\
\text { market. }\end{array}$ & $\begin{array}{l}\text { Cosmetic } \\
\text { and } \\
\text { apparel } \\
\text { store }\end{array}$ & $\begin{array}{l}\text { Selling of } \\
\text { electronic } \\
\text { goods and } \\
\text { household } \\
\text { products }\end{array}$ & $\begin{array}{l}\text { Engaged to } \\
\text { wholesale } \\
\text { and retail } \\
\text { businesses }\end{array}$ & $\begin{array}{l}\text { Deals } \\
\text { with } \\
\text { electronic } \\
\text { appliance } \\
\text { s, laptops, } \\
\text { cell } \\
\text { phones }\end{array}$ & $\begin{array}{l}\text { Artificial } \\
\text { Intelligenc } \\
\text { enith } \\
\text { Streaming, } \\
\text { e- } \\
\text { commerce, } \\
\text { cloud } \\
\text { computing }\end{array}$ \\
\hline Identifier & $\begin{array}{l}\text { Entertainm } \\
\text { ent } \\
\text { Ecommerce }\end{array}$ & $\begin{array}{l}\text { Retail } \\
\text { Ecommer } \\
\text { ce }\end{array}$ & $\begin{array}{l}\text { Retailing } \\
\text { Ecommerc } \\
\text { e }\end{array}$ & $\begin{array}{l}\text { Retail } \\
\text { Electronic } \\
\text { appliances }\end{array}$ & $\begin{array}{l}\text { Retail } \\
\text { Market } \\
\text { Merchandi }\end{array}$ & $\begin{array}{l}\text { Retail } \\
\text { Consumer } \\
\text { electronic }\end{array}$ & $\begin{array}{l}\text { Retail } \\
\text { Technolog }\end{array}$ \\
\hline
\end{tabular}


International Journal of Case Studies in Business, IT, and Education (IJCSBE), ISSN: 2581-6942, Vol. 5, No. 1, February 2021

\begin{tabular}{|c|c|c|c|c|c|c|c|}
\hline & $\begin{array}{l}\text { Media } \\
\text { Video } \\
\text { content }\end{array}$ & & $\begin{array}{l}\text { Accessori } \\
\text { es } \\
\text { Apparel } \\
\text { Fashion } \\
\text { Beauty \& } \\
\text { Fitness } \\
\text { Jewelry }\end{array}$ & $\begin{array}{l}\text { Books } \\
\text { Apparel } \\
\text { Ecommerc } \\
\text { e } \\
\text { Music } \\
\text { Sport }\end{array}$ & $\begin{array}{l}\text { se } \\
\text { Departmen } \\
\text { t stores } \\
\text { Ecommerc } \\
\text { e } \\
\text { Electronics } \\
\text { Supermark } \\
\text { ets }\end{array}$ & $\begin{array}{l}\text { S } \\
\text { Ecommer } \\
\text { ce }\end{array}$ & $\begin{array}{l}\text { y } \\
\text { Cloud } \\
\text { computing } \\
\text { Consumer } \\
\text { electronics } \\
\text { Ecommerc } \\
\text { e } \\
\text { Platform }\end{array}$ \\
\hline $\begin{array}{l}\text { Head } \\
\text { Quarter }\end{array}$ & $\begin{array}{l}\text { Englewood, } \\
\text { US }\end{array}$ & $\begin{array}{l}\text { Seoul, } \\
\text { South } \\
\text { Korea } \\
\end{array}$ & $\begin{array}{l}\text { London, } \\
\text { Great } \\
\text { Britain }\end{array}$ & $\begin{array}{l}\text { Beijing, } \\
\text { China }\end{array}$ & $\begin{array}{l}\text { Bentonville } \\
\text {, USA }\end{array}$ & $\begin{array}{l}\text { Richfield, } \\
\text { Minnesot } \\
\text { a }\end{array}$ & $\begin{array}{l}\text { Seattle, } \\
\text { US }\end{array}$ \\
\hline Workforce & 25,314 & 2,859 & 3,824 & 240,000 & $2,200,000$ & 125,000 & $1,125,300$ \\
\hline $\begin{array}{l}\text { Valuation } \\
\text { (\$) }\end{array}$ & $4.9 \mathrm{~b}$ USD & $9 \mathrm{~b}$ USD & $6.6 \mathrm{~b}$ USD & $\mathrm{N} / \mathrm{A}$ & $\begin{array}{l}411.7 \mathrm{~b} \\
\text { USD }\end{array}$ & $\begin{array}{l}29.6 \mathrm{~b} \\
\text { USD }\end{array}$ & $1.7 \mathrm{t}$ USD \\
\hline Revenue & $\begin{array}{l}\text { \$13.5b (FY } \\
\text { 2019) }\end{array}$ & $\begin{array}{l}\$ 4.1 b(Y, \\
2018)\end{array}$ & $\begin{array}{l}£ 2.4 \mathrm{~b}(\mathrm{FY}, \\
2018)\end{array}$ & $\begin{array}{l}¥ 576.9 \mathrm{~b}(\mathrm{~F} \\
\mathrm{Y}, 2019)\end{array}$ & $\begin{array}{l}\$ 524 b \text { (FY, } \\
2020)\end{array}$ & $\begin{array}{l}\$ 43.6 \mathrm{~b}(\mathrm{~F} \\
\mathrm{Y}, 2020)\end{array}$ & $\begin{array}{l}\$ 280.5 b(F \\
Y, 2019)\end{array}$ \\
\hline $\begin{array}{l}\text { Cost of } \\
\text { goods }\end{array}$ & $\begin{array}{l}\text { \$8.9b (FY, } \\
2019)\end{array}$ & N/A & $\begin{array}{l}£ 1.2 \mathrm{~b} \text { (FY, } \\
2018)\end{array}$ & $\begin{array}{l}¥ 492.5 b(F \\
Y, 2019)\end{array}$ & $\begin{array}{l}\$ 394.6 b(F \\
Y, 2020)\end{array}$ & $\begin{array}{l}\$ 33.6 \mathrm{~b}(\mathrm{~F} \\
\mathrm{Y}, 2020)\end{array}$ & $\begin{array}{l}\$ 165.5 b(F \\
Y, 2019)\end{array}$ \\
\hline Gross profit & $\begin{array}{l}\text { \$4.6b (FY, } \\
\text { 2019) }\end{array}$ & N/A & $\begin{array}{l}£ 1.2 \mathrm{~b}(\mathrm{FY}, \\
2018)\end{array}$ & $\begin{array}{l}¥ 84.4 \mathrm{~b}(\mathrm{~F} \\
\mathrm{Y}, 2019)\end{array}$ & $\begin{array}{l}\$ 129.4 b(F \\
Y, 2020)\end{array}$ & $\begin{array}{l}\text { \$10b (FY, } \\
2020)\end{array}$ & $\begin{array}{l}\$ 115 b \text { (FY, } \\
2019)\end{array}$ \\
\hline Net income & $\begin{array}{l}(\$ 405 \mathrm{~m})(\mathrm{F} \\
\mathrm{Y}, 2019)\end{array}$ & N/A & $\begin{array}{l}£ 82.4 \mathrm{~m}(\mathrm{~F} \\
\mathrm{Y}, 2018) \\
\end{array}$ & $\begin{array}{l}¥ 11.9 b(\mathrm{~F} \\
\mathrm{Y}, 2019)\end{array}$ & $\begin{array}{l}\$ 15.2 \mathrm{~b}(\mathrm{FY} \\
, 2020)\end{array}$ & $\begin{array}{l}\$ 1.5 b(F Y \\
, 2020)\end{array}$ & $\begin{array}{l}\$ 11.6 \mathrm{~b}(\mathrm{FY} \\
\text { 2019) }\end{array}$ \\
\hline
\end{tabular}

Qurate Retail Group: Among the ecommerce retailers in North America Qurate Retail, Inc is in a leading position in video commerce, also pioneers in mobile commerce and social commerce.

Coupang: is one of the largest e-commerce companies in Seoul, South Korea. The Coupang Delivery Network is so well developed that it says that more than 99 per cent of the products are delivered within 24 hours and that the arrangement is known as the Rocket Delivery Network.

ASOS: A platform for apparel and cosmetic items targeted specifically at young adults. More than 850 brands and a wide variety of clothing and accessories can be found here.

JD.com: A technology-driven e-commerce firm headquartered in Beijing, also known as Jingdong. Being one of the massive businesses for consumer online retailers, it facilitates the selling of electronic goods and household products, book, audio and video products. Advertising, logistics and other valueadded services are provided by the company.

Walmart: An American multinational company based in Bentonville, Arkansas, Walmart Inc. is a veteran in the world of retailing. The Company sells a variety of products and services at regular low prices, one of the largest retailers in the world.

Best Buy: An international consumer electronics retailer headquartered in Richfield, Minnesota. It provides in-store pickup and free delivery on a variety of products such as electornic appliances, laptops, cell phones and new technology gadgets within two days of time.

Amazon: The American multinational technology company headquartered in Seattle, Washington, offers services related to the e-commerce industry, a total cloud computing infrastructure, streaming services, and an integrated platform for artificial intelligence.

\section{SWOC ANALYSIS :}

SWOC analysis method is chosen to understand the internal and external factors which could have a negative or positive impact on the growth of the company [20]. Strength, weakness, opportunity and challenges have been identified and listed in a Table.3. Details on the points mentioned have been discussed in detail;

Table. 3: SWOC Analysis [21].

$$
\text { Strength }
$$

Weakness 


\begin{tabular}{|l|l|}
\hline $\begin{array}{l}\text { Strong footprint on Research and Development } \\
\text { Diversified business plan } \\
\text { Company Brand value } \\
\begin{array}{l}\text { Customers trust and Goodwill } \\
\text { Able leadership }\end{array}\end{array}$ & $\begin{array}{l}\text { Fall in Operational Performance } \\
\text { Vast number of merchants aboard } \\
\text { Primary dependency on domestic market }\end{array}$ \\
\hline \multicolumn{1}{|c|}{ Opportunities } & \multicolumn{1}{c|}{ Challenges } \\
\hline $\begin{array}{l}\text { Increased digital transformation trend } \\
\text { Global expansion } \\
\text { Availability of the investment }\end{array}$ & $\begin{array}{l}\text { Tough competition } \\
\text { Counterfeit products } \\
\text { Legal issues } \\
\text { Trade war }\end{array}$ \\
\hline
\end{tabular}

\section{Strength:}

Alibaba is making a significant effort in the field of Research and Development field, many patents are already registered and some are in the pipeline. They are focusing more into modern technologies such as Artificial Intelligence, Deep learning, Internet of Things etc. ET-Brain project is one of such innovation by Alibaba which is gaining popularity in Smart City, Aviation, and Agricultural domain. Alibaba has emerged as a multinational conglomerate diversifying its business into multiple verticals. Since last two decades Alibaba has built goodwill and its own brand value which wins customers trust. No doubt, founder and able leader Jack-Ma's vision and guidance are the biggest strength for Alibaba group.

\section{Weakness:}

Recent year financial report indicates that the company's operating margin declined from $26.9 \%$ in the financial year 2018 to $16.1 \%$ in the financial Year 2020, even though it gained 1\% since 2019 financial year. Alibaba platform is accommodating too many merchants and this leads to a tight competition among the merchants. Unhealthy competition may affect adversely. Alibaba's major portion of the revenue comes from Chinese consumers.

\section{Opportunities:}

Due to pandemic situation demand for digital transformation is increased, as a result cloud deployment, digital payment; web streaming etc. could attract more customers. Alibaba has good opportunity to expand its business empire to Middle East and some of the European countries as well. Attracting fund is not a big challenge for Alibaba due to its goodwill.

\section{Challenges:}

Alibaba is facing tough competition from other e-commerce companies such as Amazon, Baidu, etc legal issues and user data privacy protection has become a major concern as it may attract huge penalties. Sale of Counterfeit products on Alibaba's e-commerce platform will have adverse impact on Alibaba's brand name and goodwill. China's trade war with other countries would have negative impact on Alibaba's growth.

\section{RECCOMENDATIONS :}

Based on the SWOC Analysis, below are some of the recommendations proposed to Alibaba to overcome the current challenges and expand its business further. Firstly, Alibaba need to expand its presence beyond Asia pacific region as digital transformation is becoming an essential need of the hour due to the current pandemic situation. Alibaba's Cloud based solutions and artificial intelligence will facilitate the people in need. Secondly, competition in the field of e-commerce sector is increasing day by day. Alibaba need to continue its inorganic growth by getting into acquisition or merger of competitors. Acquisition not only combats competition, but also increases the revenue and growth possibilities. Thirdly, present artificial intelligent system being used for identification of counterfeit products to be improvised to detect all the counterfeit products while being uploaded.

\section{CONCLUSSION :}

Clear vision of the customers needs and working towards fulfilling of their requirement resulted in 
expanding Alibaba's business beyond e-commerce platform and proven to be a key success factor. As a result, customers could get most of their needs under single roof. Improved buying capacity of the middle-class consumers, stronger Chinese currency yuan, and aggressive Government policies favoring local enterprises made Alibaba group to ripe the benefit. The acquisition and integration of competitors with the Alibaba business platform further expanded the variety of customer offerings. Also, Cross promotion strategy of Alibaba group yielded benefit to subsidiary companies. Superior service, AI integrated market place, committed service level, brand value etc., played as a key factor in the journey of success. Diversification of business into different domains such a cloud computing, digital media and entertainment, logistics, Artificial Intelligence, financing beyond China territory made Alibaba group a Multinational Conglomerate.

\section{REFERENCES :}

[1] Segers, R. T. (2016). Part I China Alibaba: A Case Study on Building an International Imperium on Information and E-Commerce. In Multinational management: A casebook on Asia's global market leaders (pp. 13-32). Cham: Springer.

[2] Glowik, M. (2017). Case study: Alibaba group A successful Chinese and International digital business giant? In Global strategy in the service industries: Dynamics, analysis, growth (pp. 101102). Abingdon, Oxon: Routledge.

[3] Alibaba Group - Funding, Financials, Valuation \& Investors. (n.d.). Retrieved January 10, 2021, from https://www.crunchbase.com/organization/alibaba/company financials

[4] Aithal, P. S., (2017). Company Analysis - The Beginning Step for Scholarly Research. International Journal of Case Studies in Business, IT and Education (IJCSBE), 1(1), 1-18.

[5] Turban, E., Outland, J., King, D., Lee, J. K., Liang, T., \& Turban, D. C. (2018). Business-toBusiness E-Commerce. In Electronic Commerce 2018: A Managerial and Social Networks Perspective (pp. 123-166). Cham: Springer International Publishing.

[6] Sciaudone, Antonio (2018). Equity research - Alibaba Group. Master's Dissertation, University of Lisbon. Higher Institute of Economics and Management, 1-50.

[7] Our Businesses. (n.d.). Retrieved January 19, 2021, from https://www.alibabagroup.com/en/about/businesses

[8] Blystone, D. (2021, January 18). Understanding the Alibaba Business Model. Retrieved January 20, 2021, from https://www.investopedia.com/articles/investing/062315/understanding-alibabasbusiness-model.asp

[9] Kwak, J., Zhang, Y., \& Yu, J. (2019). Legitimacy building and e-commerce platform development in China: The experience of Alibaba. Technological Forecasting and Social Change, 139(1), 115124.

[10] Anwar, S.T. (2017). Alibaba: Entrepreneurial growth and global expansion in B2B/B2C markets. $J$ Int Entrep. 15(1), 366-389.

[11] Huang, L., Hu, G., \& Lu, X. (2009). E-business Ecosystem and its Evolutionary Path: The Case of the Alibaba Group in China. Pacific Asia Journal of the Association for Information Systems, 1(4), 3rd ser., 25-36.

[12] Alibaba Group Announces September Quarter 2020 Results. (2020, November 05). Retrieved January 14, 2021, from https://www.businesswire.com/news/home/20201105005549/en/AlibabaGroup-Announces-September-Quarter-2020-Results

[13] Alibaba Reports September 2020 Quarter Earnings. (2020, November 05). Retrieved January 14, 2021, from https://www.alizila.com/alibaba-reports-september-2020-quarter-earnings/

[14] Zacks Investment Research. (2021, January 28). Member Sign In. Retrieved January 29, 2021, from https://www.zacks.com/stock/chart/BABA/fundamental/revenue-quarterly-yoy-growth 
International Journal of Case Studies in Business, IT, and Education (IJCSBE), ISSN: 2581-6942, Vol. 5, No. 1, February 2021

[15] Alibaba Free Cash Flow 2011-2020: BABA. (n.d.). Retrieved January 15, 2021, from https://www.macrotrends.net/stocks/charts/BABA/alibaba/free-cash-flow

[16] Schmidpeter, R., Lu, H., Stehr, C., \& Huang, H. (2015). The Philanthropy and Motivation of Jack Ma. In Sustainable Development and CSR in China a Multi-Perspective Approach (pp. 126-127). Cham: Springer International Publishing.

[17] Zhu, X., Jiang, W., Liu, F., Zhang, Q., Pan, L., Chen, Q., \& Jia, Z. (2020). Heat to Power: Thermal Energy Harvesting and Recycling for Warm Water-Cooled Datacenters. 2020 ACM/IEEE 47th Annual International Symposium on Computer Architecture (ISCA), 405-418.

[18] Yen, B. \& Wong, G. (2019) Case study: Cainiao and JD.com leading sustainability packaging in China. Proceedings of the 19th International Conference on Electronic Business (pp. 90-98). ICEB, Newcastle upon Tyne, UK, December 8- 12.

[19] Alibaba competitors. (n.d.). Retrieved January 14, 2021, from https://craft.co/alibaba/competitors

[20] Aithal, P. S. and Kumar, P. M., (2015). Applying SWOC Analysis to an Institution of Higher Education. International Journal of Management, IT and Engineering, 5(7), 231-247.

[21] Jaswal, N., Sharma, T., Kanwal, D., \& Chopra, P. (2020, April). Alibaba Group Holding Ltd. Company Analysis. Retrieved January 15, 2021, from https://www.researchgate.net/publication/340443444_Alibaba_Group_Holding_Ltd_Company $\underline{\text { Analysis }}$ 